all-he made anthropological observations, and collected ethnographical objects. These are now in the Ethnographical Museum in Florence, and illustrations of a considerable number of them are found in his work. Besides these tribes, the book also deals with the Bashkirs and Kirghises, whom the author visited in returning to Europe.

THE last Bulletin (No, 6) of the Geographical Society of Belgium contains a paper by M. Oscar Royer describing his journey on the Congo; notes on a journey in Texas, by Mr. Lancaster; also "Some words on Atlantis," by M. de Bloek, who regards this fabulous region as merely one of those invented by the ancients for the purpose of working out in imagination their social and political theories. Finally, a study on the first narrative of Columbus, and the old printed editions of it, with a fac-simile of the first "Epistola C. Coloni," printed at Antwerp in 1493 .

\section{THE INSTITUTION OF MECHANICAL ENGINEERS}

T'HIS Institution held its annual general meeting in London last week. The list of papers to be read we have already given, though some of them were not read; the only one calling for special notice at our hands is that of Sir Frederick Abel on a "Final Report bcaring upon the Question of the Condition in which Carbon exists in Steel." The following are the conclusions which Sir Frederick bases on the present and on the two preceding reports :-

" The results of the experimental work described appear to warrant the following conclusions in regard to characteristics, recognisable by chemical examination, which are exhibited by different portions of one and the same sample of steel presenting marked physical difterences consequent upon their exposure to the hardening, annealing, or tempcring processes.

(I) In annealed steel the carbon exists entirely, or nearly so, in the form of a carbide of iron, if uniform composition $\left(\mathrm{Fe}_{3} \mathrm{C}\right.$ or a multiple thereof), uniformly diffused through the mass of metallic iron.

"(2) The cold-rolled samples of steel examined were closely similar in this respect to the annealed steel, doubtless because of their having been annealed between the rollings.

" (3) In hardened steel the sudden lowering of the temperature from a high red heat appears to have the effect of preventing or arresting the separation of the carbon, as a definite carbide, from the mass of the iron in which it exists in combination ; its condition in the metal being, at any rate mainly, the same as when the steel is in a fused state. The presence of a small and variable proportion of $\mathrm{Fe}_{3} \mathrm{C}$ in hardened steel is probably due to the unavoidable and variable extent of imperfection, or want of suddenness, of the hardening operation; so that, in some slight and variable degree, the change due to annealing takes place prior to the fixing of the carbon by the hardening process.

"(4) In tempered stcel the condition of the carbon is intermediate between that of hardened and of annealed steel. The maintenance of hardened steel in a moderately heated state causes a gradual separation (within the mass) of the carbide molecules, the cxtent of which is regulated by the degrec of heating, so that the metal gradually approaches in character to the anncaled condition: but, even in the best result obtained with blue-tempered steel, that approach, as indicated by the proportion of separated carbide, is not more than about half-way towards the condition of annealed stecl.

"(5) The carbide separated by chemical treatment from blueand straw-tempered stecl has the same composition as that obtained from annealed steel.

"It does not appear that this inquiry can be further extended with the prospect of obtaining any additional facts-elucidating the condition of the carbon in steel exhiliting various physical characteristics-the vaiue of which would bear any proportion to the very laborious nature of the neccssary experimental work, which has to be cooducted with small quantities of material on account of the necessity of carrying out the annealing, hardening, and tempering processes with very thin pieces of steel.

"I believe it will be admitted that, although the data obtained have not led to the discovery of a ready chemical method of differentiating between different degrees of temper in steel (a method of examination which Prof. Hughes's interesting results have almost rendered unnecessary), they have at any rate contributed to the advancement of our knowledge of the nature of steel."

\section{THE INFLUENCE OF DIRECT SUNLIGHT ON VEGETATION}

THE influence of direct sunlight on vegetation is generally known, but surely deserves to be a subject of special study. In the following paper we shall only endeavour to describe some facts with relation to this influence. In the first place, the effect of the sun's rays in the tropical regions will be traced, and afterwards in the temperate and arctic zones. The constant high temperature within the tropics is the cause of the plants being less dependent on the direct solar heat than is the case in the greater part of the temperate and cold zones, but, notwitstanding this, there are plants even in the tropical regions requiring for a luxuriant growth the direct rays of the sun.

Of the tropical monocotyledonous plants, the palms arc doubtless the most important, and of these the date-palm of the Sahara Desert (Phenix dactylifera, L.) furnishes daily food to the inhabitants of this part of Africa.

It is known that the subterranean wells are the only cause of vegetation in this desert. When a well is discovered, in a short time an oasis arises, and the date-palm appears.

Considering that the first condition for the growth of palms is a humid soil wherein the roots may vegetate, there seems to be at first something strange in the fact of the Great Desert producing species of this family; but the Arabs say that this "Queen of the Onsis" puts her feet in water and her head in the fire of heaven; and this is the cause of the rapid growth of the plant (Greisbach, "Die Vegetation der Erde," Theil ii. p. 87) ; the water ascends by the roots into the tissue of the tree, and communicates its temperature to the inner parts, so that the influence of the sun's heat is tempered ; the evaporation of the plant also causes a lower temperature; thus it withstands a difference of $98^{\circ}$ (from $126^{\circ}$ to $28^{\circ}$ ), as occurs in the Desert (Martins, "Le Sahara," Revue des deux Mundes, 1864, vol. lii. p. $\left.6 \mathrm{r}_{3}\right)$.

Though, as we have said above, these plants require, in the first place, water for their roots, the fact of the stems growing in their wild state at a considerable distance the one from the other, and never forming dense forests, proves that they require also the light.

But the date-palm is indigenous to the Great Desert; nowhere else does this plant vegetate so rapidly. When cultivated with success, it is also in a descrt-climate, as, for instance, in that of Murcia in Spain (the date forest of Elche), the highlands of Afghanistan, \&c. The cause of its culture being without fruits in the Mediterranean is the dry summer, there being no subterranean wells, as is the case in the Sahara.

The sugar-cane (Saccharum officinarum, L.) is also a plant requiring the direct solar light; moist climates are disadvantageous to its cultivation. Thus the climate of China, with its heavy rains in May and June (Dove, "Klimatologische Beiträge," vol. i. p. 102), but less precipitation in autumn, when the fruits ripen, is suited for the culture of this plant. It is known that the quantity of sugar depends on the quantity of sunshine.

l'urning to the warm temperate zone we see the species of citrus cultivated in the sunny climate of Southern Italy, and even by cultivation produce the delicious fruits generally known, because they are in summer under the almost constant influence of the sun's rays in open localities. In the Malayan Peninsula, the supposed native country of these plants, they also grow in open spaces and not in the jungles, requiring a moist soil, but also the solar light, to ripen their fruits; this explaius why the finest and largest oranges are obtained when the trees are trained against walls, as is the case in some parts of Southern England.

The vine (Vitis vinifera, L.) is also a plant requiring heat in the after summer to ripen its fruits ; the climate of Southern France and Italy is thereforc well adapted for its cultivation. In the continental climate of Bokhara in Furkestan $\left(40^{\circ} \mathrm{N}\right.$. lat. $)$, with its hot summer. (in the sandy desert on the Oxus River the soil was found to have a temperature of $144^{\circ}$ - Basiner, "Reise durch die Kirgisensteppe nach (hiwa"), the plant is cultivated in the open fields; its winter covering is not taken off before the end of March, but in April the temperature is already very high, and in July it becomes insupportable $;^{1}$ the fruit of the vire is ripe by the end of June or the beginning of July. The soil is moistened here by artificial irrigation. A

I Mean temperature at Samarkand, lat. $39^{\circ} 39^{\prime}$, in $188 \mathrm{x}$ : April $6 \mathrm{I}^{\circ}$, May $70^{\circ}$, June $77^{\circ}$, July $8 r^{\circ}$, August $77^{\circ}$, September $68^{\circ}$, and December $28^{\circ}$; mean temperature at I p.m. in June $86^{\circ}$, in July $93^{\circ}$, in August $92^{\circ}$, in September $8 r^{\circ}$. 